\title{
Announcement from Editorial Board
}

The following article has been retracted due to the investigation of complaints received against it. The Editorial Board found that substantial portions of the text came from other published papers. The scientific community takes a very strong view on this matter, and the Open Journal of Animal Sciences treats all unethical behavior seriously. This paper published in Vol.4 No.5, 228-236, 2014 has been removed from this site.

Title: Hormones in Poultry Production: Scientific Facts

Authors: Wagner Azis Garcia de Araújo, Tarcisio Simões Pereira Agostinho, Nielton Cezar Ton, Luiz Fernando Teixeira Albino

Open Journal of Animal Sciences Editorial Board

September 28, 2014 